\title{
The deeper we go the less we know
}

\author{
C. Menza, M. Kendall \& S. Hile \\ National Oceanic and Atmospheric Administration, Center for Coastal Monitoring and Assessment, Biogeography \\ Branch, 1305 East-West Highway Silver Spring MD 20910; charles.menza@noaa.gov
}

Received 15-VII-2007. C Corrected 10-XI-2007. ～Accepted 13-II-2008.

\begin{abstract}
The relatively recent and well-documented decline of coral cover among reefs around the world has stimulated numerous publications on coral reef ecology and in particular coral reef mortality. These studies have predominantly collected data from nearshore, shallow coral reefs. This concentration on shallow sites provides an incomplete and biased view of coral reefs because many reefs lie entirely or partially below this depth. In this report we quantified the bias of coral reef literature towards shallow reefs using a scientific literature survey. In addition, a case study based on data collected from a range of depths and distances from shore in the US Virgin Islands demonstrates that the deepest reefs farthest from shore have the highest live coral cover. Taken together, these data suggest that reefs with the most live coral cover are also the least studied. Rev. Biol. Trop. 56 (Suppl. 1): 11-24. Epub 2008 May 30.
\end{abstract}

Key words: Coral Reefs, Deep, Bias, Remotely Operated Vehicles, US Virgin Islands.

Broad-scale studies in many parts of the world have shown dramatic declines of live coral cover the past three decades (Hughes 1994, Rogers and Beets 2001, Gardner et al. 2003). Implicated stressors include coastal development, coral disease, coral bleaching, hurricanes, and harmful fishing practices (e.g., Rogers 1991, Rogers and Beets 2001, Bellwood et al. 2004, Chiappone et al. 2002), many of which are expected to be exacerbated by population growth and global warming in the near future (Hoegh-Guldberg 1999). Some studies have shown that deeper reefs may be sheltered from many of the stressors that shallow reef systems must endure (Bak and Niewland 1995, Bak et al. 2005). For example, deeper reefs may be insulated from hot, shallow water masses that cause bleaching, and are generally farther offshore than shallow reefs thus insulating them from many anthropogenic, land-based, stressors (Glynn 1996). These observations and conclusions have resulted in the impression that deep reefs could serve as potential refugia for shallow reef organisms during times of stress (Glynn 1996, Riegl and Piller 2003, Bak et al. 2005).

Despite this speculation about the relative condition of deep versus shallow reefs (Glynn 1996, Riegl and Piller 2003, Bak et al. 2005), deep reefs have received relatively little scientific scrutiny. Most of the studies documenting the decline of reefs are limited to conspicuous and easily-accessible shallow $(<30 \mathrm{~m})$ reef ecosystems. In fact, much of our understanding of coral reef ecology in general is based on these relatively shallow depths. Far less is known of mesophotic (30 $\mathrm{m}-100 \mathrm{~m})$ and deep (>100 m) reefs due to the limits of basic scuba training and the costs associated with remote sensing technologies. While the proportion of studies in deep versus shallow systems is probably heavily skewed toward shallow areas, the extent of this present bias has not been quantified. 
The objectives of this report are to highlight the knowledge gap for mesophotic and deep reefs relative to shallow ones, and present new data characterizing reefs in the U.S. Virgin Islands from a range of depths and distances from land.

\section{MATERIALS AND METHODS}

Literature Survey: We conducted a survey of recent peer-reviewed scientific articles to investigate the depths at which coral reef studies have been made. The survey used keywords and subject category designations to obtain a representative population of articles on coral ecology from the Science Citation Index Expanded (ISI Web of Science, Thomson Scientific). All articles in the citation index (1984-2005) which included the topic keywords "coral OR corals", were in marine and freshwater biology, environmental science, ecology, or zoology subject categories and did not include the topic keyword "coral reef fish*" were used to generate the population of relevant articles. An asterisk is used as a catchall term so that any letter or group letters can be included in the position of the asterisk.

A second more refined survey added the keywords "health OR mortal*" to the search criteria defined above. This was done in order to obtain a population of articles on coral ecology targeting coral health and mortality due to the heightened interest and importance of this topic in recent literature.

Fifty articles were randomly chosen from each population of articles to obtain a representative sample. These articles are presented in Appendix A. If a selected article did not implicitly gather data on coral reefs at a known depth, the article was eliminated from the sample and a new article was randomly chosen in its place. Individual studies consisted of one or several coral reef sites listed at either discrete depths or through a range of depths. Depth of each study was recorded as the depth of observations or measurements for in situ studies, coral collection sites for lab studies, or transplant sites. All these contribute to knowledge of coral reefs at specific depths. Depth of study reefs were plotted for each of the 50 articles in both literature searches. The total number studies were then tallied within $5 \mathrm{~m}$ depth classes in histograms for both literature searches.

Caribbean Case Study: Estimates of live coral cover were determined for coral reefs on the insular shelf south of the islands of St. Thomas and St. John, US Virgin Islands (see Figure 1). This area is characterized by a network of reefs which range in depths from 10 $\mathrm{m}$ to $70 \mathrm{~m}$.

A Spectrum Phantom S2 remotely operated vehicle (ROV) deployed off the NOAA ship Nancy Foster in February 2005 was used to obtain reef data. Forty-nine transects were completed between St. John, St.Thomas, and the insular shelf edge. Transects were placed to obtain representative samples of the region's benthic habitats and include as many transitions among habitats as possible. Distinct habitat features and transitional areas were determined from spatial patterns in fine-scale multibeam data acquired during the same mission.

A high-resolution camera and strobe attached to the ROV acquired images of the seafloor along transects. Still images were acquired systematically every 30 seconds along the distance of each transect. The speed of the ROV was kept between 0.5 and $1 \mathrm{~m} \mathrm{~s}^{-1}$ which resulted in images spaced approximately every $16 \mathrm{~m}( \pm 1.7)$. Each image was estimated to cover 1 square meter area $\pm 50 \mathrm{~cm}$. An ultra-short baseline system and differential geographic positioning system were used to determine the geographic location of each image within approximately $5 \mathrm{~m}$. A pressure sensor mounted on the ROV was used to determine depth.

For each image, the relative area of live coral was estimated visually with the aid of a 10 X 10 grid superimposed on each image. Images were used to estimate live coral cover on 13 areas of hermatypic reef (Figure 1). These areas represented isolated reefs, surrounded by sand or rhodoliths, or portions of a single reef (e.g. mid-shelf ridge complex) separated by 

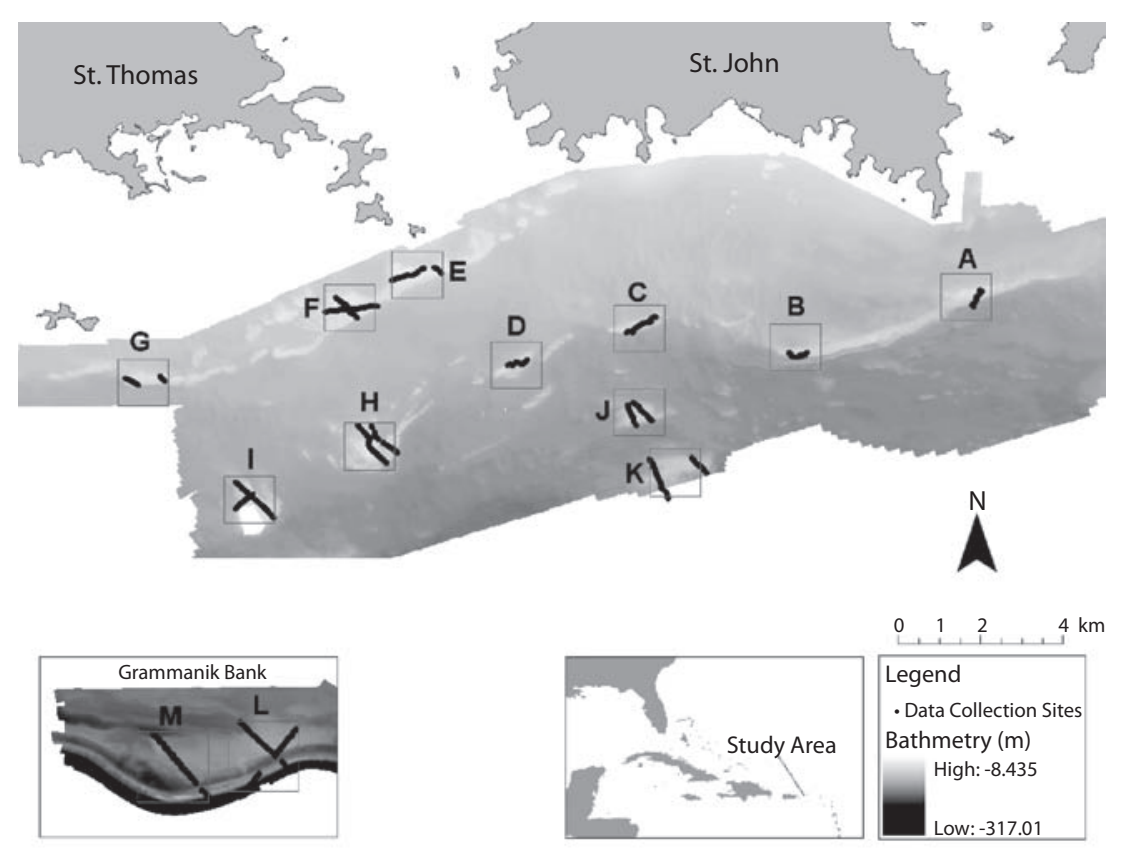

Fig. 1. Study area. The locations of investigated reef areas (A-M) are denoted by boxes. Data collection sites represent location of still images.

more than $500 \mathrm{~m}$. Estimates of live coral cover, distance from shore and depth were calculated by averaging data among still images on each reef area (Table 1 ).

Estimates of live coral cover were examined in relation to average depth and distance from shore. Logarithmic trends were used to model relationships, because they explained more variance than alternative forms (e.g. linear) and coral cover reached an asymptote at higher values of depth and distance.

\section{RESULTS}

Literature Search: The general coral ecology and coral health/mortality literature searches yielded 4920 and 844 articles, respectively. The two samples of 50 articles represented approximately $1 \%$ and $6 \%$ of the corresponding target populations.

Examination of the depths at which studies investigated coral reefs shows an extreme bias in the scientific literature towards reefs shallower than $30 \mathrm{~m}$ (Figure 2). In both searches, an exponential decline in studies was observed with increasing depth strata. Studies representing general coral reef ecology were proportionally few below $15 \mathrm{~m}$ and extremely rare below $30 \mathrm{~m}$. Similarly, studies on coral health or mortality below $30 \mathrm{~m}$ were also extremely rare.

Caribbean Case Study: Analysis of live coral cover among the 13 investigated insular shelf reef areas shows live cover was generally higher among deeper reefs and reefs further from land (Figure 3). Univariate logarithmic models for depth and distance from shore explained $50 \%$ and $56 \%$ respectively of the variability in live coral cover. Two of the sites were clearly the farthest from shore and deepest in the study (Figure 3 l-m; Grammanik Bank). These were excluded from the regressions and the models were re-evaluated to determine if these two points were disproportionately influencing model fit. Without them, model fit for 
TABLE 1

Summary statistics for 13 reef areas. Distance from shore and depth represent averages taken from all images on a given reef area

$\begin{array}{ccccc}\begin{array}{c}\text { Reef } \\ \text { Area }\end{array} & \begin{array}{c}\text { Live Coral } \\ \text { Cover }(\%)\end{array} & \begin{array}{c}\text { Number of } \\ \text { Replicates }\end{array} & \begin{array}{c}\text { Distance from } \\ \text { Shore }(\mathrm{km})\end{array} & \begin{array}{c}\text { Depth } \\ (\mathrm{m})\end{array} \\ \text { A } & 13.0 & 32 & 2.4 & 29.1 \\ \text { B } & 9.5 & 36 & 4.3 & 26.3 \\ \text { C } & 15.6 & 60 & 4.0 & 26.8 \\ \text { D } & 4.4 & 33 & 5.1 & 26.5 \\ \text { E } & 1.4 & 65 & 3.9 & 19.1 \\ \text { F } & 2.8 & 171 & 3.9 & 19.4 \\ \text { G } & 16 & 30 & 4.5 & 23.7 \\ \text { H } & 23.4 & 144 & 7.1 & 27.5 \\ \text { I } & 36.0 & 114 & 7.8 & 26.4 \\ \text { J } & 52.4 & 78 & 6.3 & 31.6 \\ \text { K } & 46.4 & 93 & 7.5 & 28.8 \\ \text { L } & 45.4 & 132 & 14.4 & 53.1 \\ \text { M } & 41.0 & 148 & 14.0 & 52.8\end{array}$

live coral cover and depth had an $\mathrm{R}^{2}$ of 0.51 and live coral and distance from shore had an $\mathrm{R}^{2}$ of 0.50 . These values and corresponding trends are similar to the model with all points included. Distance from land and depth were sufficiently collinear in this area that multiple regression involving both variables was not appropriate.

\section{DISCUSSION}

The skew demonstrated in the scientific literature on coral reefs toward shallow systems is striking. Whether the subject is general coral reef science or the more specialized topic of coral health and mortality, there is an exponential decline in knowledge of reefs with increasing depth. These declines are likely conservative estimates, since articles published before 1984 were not included in the article populations and these were predominantly in shallow reef environments.

Studies conducted shallower than $20 \mathrm{~m}$ dominate reef science due to their accessibility with basic SCUBA training and ease of access from shore. Beyond this depth, the knowledge of reefs rapidly tails off such that below $30 \mathrm{~m}$, reef systems are known through very few studies. This results in a "shallow reef" bias in the scientific community's understanding of reef ecosystems. Assuming that the same processes, stressors, health issues, and rates of change operate at the same level for deeper reefs farther offshore may be inappropriate. Deep reefs at the edge of the photic zone may be both more susceptible to particular stresses, such as shading by turbidity, and also insulated from others such as warm surface waters in areas with thermal stratification of the water column. Similarly, reefs further from shore may be more susceptible to stresses originating off insular and continental shelves such as cold water influxes and also isolated from land-based pollution and sedimentation.

A fundamental component of reef research is knowledge of their locations. The spatial extent of deep reefs is poorly documented relative to their more extensively mapped shallow 

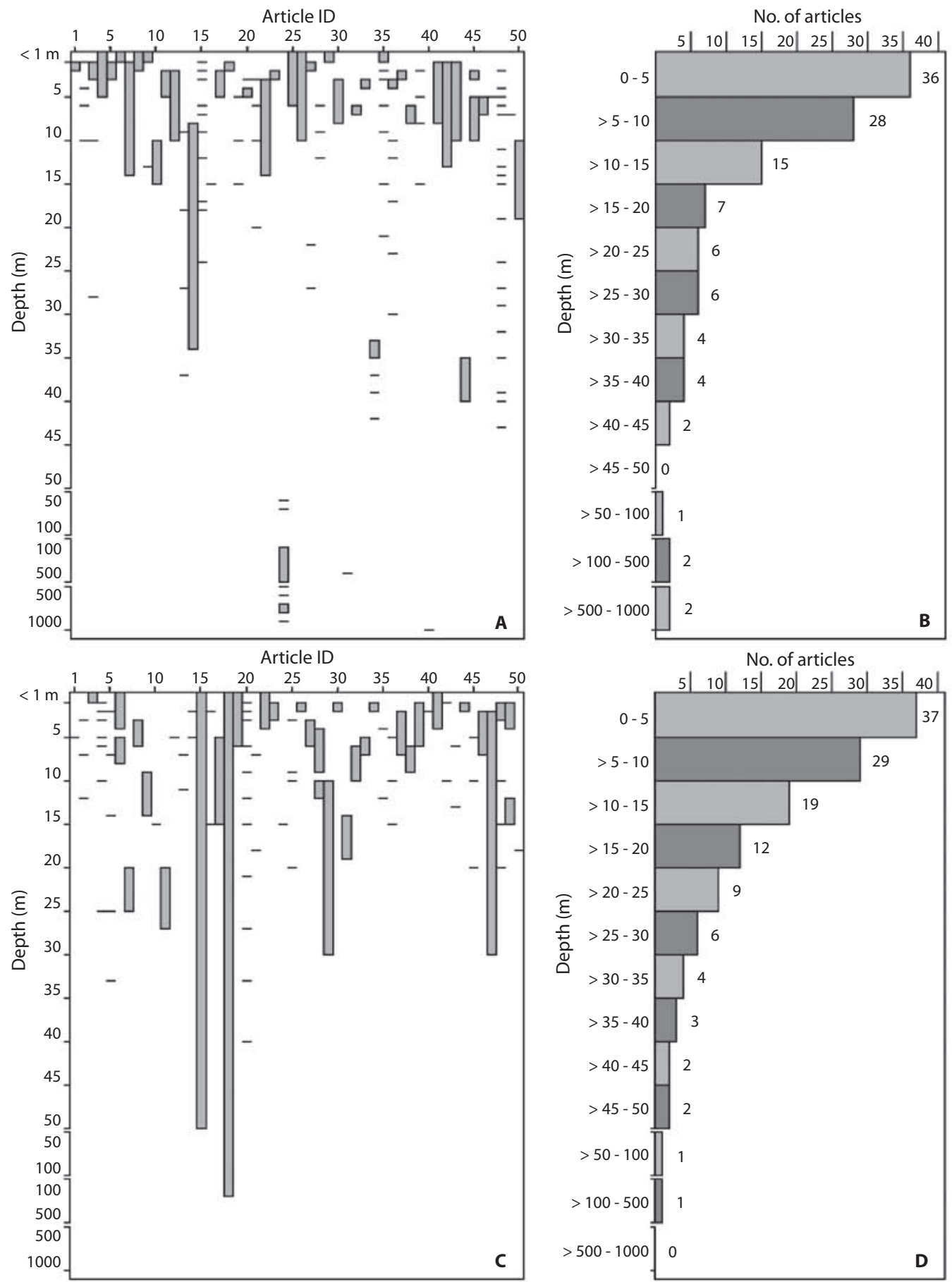

Fig. 2. Results of literature reviews for scientific articles on corals (A and B) and specific to coral health or mortality (C and D). Depth charts on the left (A and C) represent the depth(s) at which studies or observations were made. Depth ranges are shown by vertical bars. Histograms on the right (B and D) show the number of articles with studies or observations among 5 meter depth intervals. 

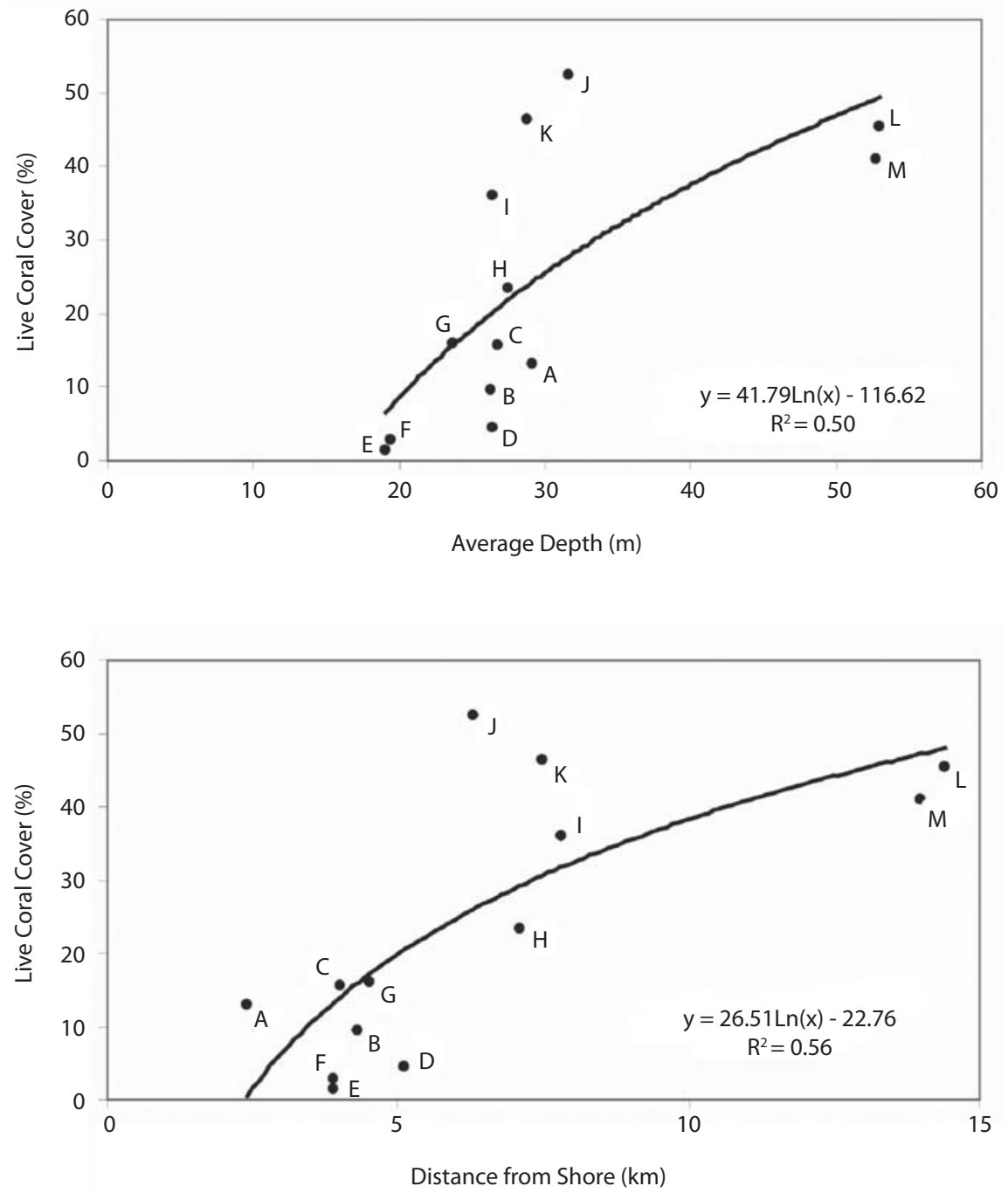

Fig. 3. Models of percent live coral cover at 13 reef areas (A-M) using depth (top) and distance from shore (bottom).

counterparts. This basic information is critical to understand the processes which affect deep reefs. Recent advances in deep water (>30m) coral mapping using techniques such as multibeam sonar (e.g., Roberts et al. 2005, Grasmueck et al. 2006) will eventually inform this potential discrepancy. It is not known if the decline in reef science with depth is proportional to a decline in reef area with depth. More certain however, is that deeper reefs still in the photic zone harbor many of the same species as shallow reefs (e.g., Monaco et al. 2007) and, as in the US Virgin Islands, often have greater live coral cover.

Although deep reefs may be insulated from some deleterious impacts, especially those associated with man, they cannot be considered unequivocally invulnerable, e.g., Menza et al. (2007). Cold water intrusion (Leichter et al. 1996, Leichter and Genovese 2006), descended dense water masses (Dennis and Wicklund 1994, Hickey et al. 2000, Smith 2001), sedi- 
mentation (Bak et al. 2005), turbidity, and infectious diseases (Riegl and Piller 2003) can adversely impact deep reef corals.

This is the first study to statistically define the relationship between coral cover among reefs from a wide range of depths and distances from land. Deep reefs far from shore had much higher coral cover than their shallow counterparts closer to shore. Greater depth may insulate corals from hot water masses that may cause bleaching provided that adequate thermal stratification restricts such warm, low density waters to surface layers (Glynn 1996). Greater distance from shore may insulate corals from land-based stressors such as sedimentation, turbidity and salinity changes associated with runoff, nitrification associated with groundwater seeps or sewage outfalls, and pollution, all of which are known to negatively impact corals (Rogers 1990, Lirman et al. 2003, Fabricius 2005, Cleary et al. 2006, Ramade and Roche 2006, Restrepo et al. 2006, Lapointe and Bedford 2007). More direct impacts associated with human use may affect corals as well. Anthropogenic impacts may include boat groundings (Riegl 2001), commercial and recreational fishing (Chiappone et al. 2002, Hawkins and Roberts 2004) and diving (Barker and Roberts 2004). Reefs closer to ports or close to shore are simply more accessible, economical to reach, and allow easier and longer recreational diving opportunities than deeper reefs farther offshore.

Linear fit between live coral cover and depth and distance to shore fit the data well, but did not explain as much of the variance in the relationship as the logarithmic fit. This makes sense since live coral cover would be expected to level off at deep and far from shore reefs. Once the depth limit of light penetration adequate for photosynthesis is approached, live coral cover should level off (and with even greater depth would begin to decline). Once the harmful effects encountered at locations closer to shore are overcome by increased distance offshore, no further benefit and enhancement of live coral cover would be expected at even greater distances.
Depth and distance from shore are collinear in our case study and could be expected in most others. Therefore, separating the effects of the variables is difficult and should be tested in other areas with reef at a variety of combinations of depth and distance to land.

The reef closest to shore in this study was 2.4 km from St. John (Reef area A). Recent surveys of the reefs around St. John (e.g., Monaco et al. 2007) provide insight into characteristics of reefs closer to shore. Estimates of average live coral cover are approximately 6\%, if all reef habitat types are assessed together, or $15 \%$, if only spur and groove and linear reef habitat types are included (Data source: NOAA Biogeography Branch 2007). The reef types used to generate the latter are reef types similar to those surveyed by the ROV. These nearshore reefs are negatively affected by land based processes and human use (Rogers and Beets 2001). In addition, elevated surface water temperatures would be expected to impact these reefs first and longer than their deeper counterparts. The relatively low coral cover estimates from nearshore shallow reefs correspond with the deep reefs closest to shore in our dataset.

Taken together, the literature search and case study suggest that reefs in the USVI with the most live coral cover are also the least studied. There is no reason to believe that the pattern in live coral cover observed here would differ for similar insular and shelf environments elsewhere.

The outlook for shallow reefs is dire (Bellwood et al. 2004, Wilkinson 2004). Less certain are predictions for deeper reefs. In the broad shelf area south of the US Virgin Islands it appears that live coral cover remains at the impressive levels once observed in shallower reefs closer to shore (Rogers and Miller 2006). This however is a well studied region and adds only a handful of sites to the list of studies examining deep reefs. It is unknown if similar patterns of coral cover are present in deeper reefs elsewhere and if these deep reefs will remain beyond the influence of forces harming shallow reefs such as global climate change and deleterious human impacts. 


\section{ACKNOWLEDGMENTS}

We thank Lance Horn, Glenn Taylor, and Jeffrey Williams, the staff of the NOAA ship Nancy Foster, Paige Rothenberger, Jason Vasquez, and Tim Battista for their outstanding operational support in the field.

\section{RESUMEN}

La reciente reducción en la cobertura de coral en los arrecifes alrededor del mundo ha dado lugar a numerosas publicaciones sobre la ecología de los arrecifes de coral, y particularmente sobre la mortalidad de los corales. Estos estudios fueron realizados con datos recolectados principalmente cerca de la orilla y en aguas poco profundas. La información sobre los corales obtenida de los sitios de poca profundidad es incompleta y sesgada, ya que muchos arrecifes se encuentran total o parcialmente a una mayor profundidad. En este estudio, cuantificamos el sesgo en la literatura de arrecifes de poca profundidad, mediante un análisis de la literatura científica. Además, un estudio basado en los datos recolectados a varias profundidades y a distintas distancias de la orilla en las Islas Vírgenes de los Estados Unidos, demuestra que los arrecifes que están a una mayor profundidad y más alejados de orilla, tienen una mayor cobertura de coral vivo. Tomando ambos estudios en cuenta, estos datos sugieren que los arrecifes con la mayor cobertura de coral vivo son también los menos conocidos.

Palabras clave: arrecifes de coral, profundidad, sesgo, vehículo de observación remota, Islas Vírgenes, Estados Unidos.

\section{REFERENCES}

Armstrong, R.A., H. Singh, J. Torres, R.S. Nemeth, A. Can, C. Roman, R. Eustice, L. Riggs \& G. Garcia-Moliner. 2006. Characterizing the deep insular shelf coral reef habitat of the Hind Bank marine conservation district (US Virgin Islands) using the Seabed autonomous underwater vehicle. Cont. Shelf. Res. 26: 194-205.

Bak, R.P.M. \& G. Nieuwland. 1995. Long-term change in coral communities along depth gradients over leeward reefs in the Netherlands-Antilles. Bull. Mar. Sci. 56: 609-619.

Bak, R.P.M., G. Nieuwland \& E.H. Meesters. 2005. Coral reef crisis in deep and shallow reefs: 30 years of constancy and change in reefs of Curacao and Bonaire. Coral Reefs 24: 475-479.

Barker, N.H.L. \& C.M. Roberts. 2004. SCUBA diver behaviour and the management of diving impacts on coral reefs. Biol. Conserv. 120: 481-489.
Bellwood, D.R., T.P. Hughes, C. Folke \& M. Nystrom. 2004. Confronting the coral reef crisis. Nature 429: 827-833.

Chiappone, M., A. White, D.W. Swanson, \& S.L. Miller. 2002. Occurrence and biological impacts of fishing gear and other marine debris in the Florida Keys. Mar. Pollut. Bull. 44: 597-604.

Cleary, D.F.R., Suharsono \& B.W. Hoeksema. 2006. Coral diversity across a disturbance gradient in the Pulau Seribu reef complex off Jakarta, Indonesia. Biodiversity and Conserv. 15: 3653-3674.

Dennis, G.D. \& R.I. Wicklund. 1994. The relationship between environmental factors and coral bleaching at Lee Stocking Island, Bahamas, in 1990. pp 167-173. In: R.N. Ginsburg (compiler). Proc. Colloq. Global Aspects Coral Reefs: Health, Hazards and History. RSMAS, Univ. Miami, Miami, Florida.

Fabricius, K.E. 2005. Effects of terrestrial runoff on the ecology of corals and coral reefs: review and synthesis. Mar. Poll. Bull. 50: 125-146.

Gardner, T.A., I.M. Cote, J.A. Gill \& A. Grant \& A.R. Watkinson. 2003. Long-term region-wide declines in Caribbean corals. Science 301:958-960.

Glynn, P.W. 1996. Coral reef bleaching: facts, hypothesis and implications. Global Change Biol. 2: 495-509.

Grasmueck, M., G.P. Eberli, D.A. Viggiano, T. Correa, G. Rathwell \& J.G. Luo. 2006. Autonomous underwater vehicle (AUV) mapping reveals coral mound distribution, morphology and oceanography in deep water if the Straights of Florida. Geophys. Res. Lett. 33: L23626.

Hawkins, J.P. \& C.M. Roberts. 2004. Effects of artisanal fishing on Caribbean coral reefs. Conserv. Biol. 18: 215-226.

Hickey, B.M., P. MacCready, E. Elliot \& N.B. Kachel. 2000. Dense saline plumes in Exuma Sound, Bahamas. J. Geophys. Res. 105: 11471-11488

Hoegh-Guldberg, O. 1999. Climate change, coral bleaching and the future of the world's coral reefs. Mar. Freshwater Res. 50: 839-866.

Hughes, T.P. 1994. Catastrophes, phase-shifts, and largescale degradation of a Caribbean Coral Reef. Science 265: 1547-1551.

Lapointe, B.E. \& B.J. Bedford. 2007. Drift rhodophyte blooms emerge in Lee County, Florida, USA: Evidence of escalating coastal eutrophication. Harmful Algae 6: 421-437. 
Leichter, J.J., S.R. Wing, S.L. Miller \& M.W. Denny. 1996. Pulsed delivery of subthermocline water to Conch Reef (Florida Keys) by internal tidal bores. Limnol. Oceanogr. 41: 1490-1501.

Leichter, J.J. \& S.J. Genovese. 2006. Intermittent upwelling and subsidized growth of the scleractinian coral Madracis mirabilis on the deep fore-reef slope of Discovery Bay, Jamaica. Mar. Ecol. Prog. Ser. 316: 95-103.

Lirman, D., B. Orlando, S. Macia, D. Manzello, L. Kaufman, P. Biber \& T. Jones. 2003. Coral communities of the Biscayne Bay, Florida and adjacent offshore areas: diversity, abundance, distribution and environmental correlates. Aquat. Conserv. Mar. Freshwat. Ecosyst. 13: 212-135.

Monaco, M.E., A.M. Friedlader, C. Caldow \& J.D. Christensen. 2007. Characterizing reef fish populations and habitats within and outside the US Virgin Islands Coral Reef National Monument: a lesson in marine protected area design. Fish. Manag. Ecol. 14: 33-40.

Ramade, F. \& H. Roche. 2006. Pollutant effects on coral reefs ecosystems. Rev. Ecol. (Terre Vie) 61: 3-33.

Restrepo, J.D., P. Zapata, J.A. Diaz, J. Garzon-Ferreira \& C.B. Garcia. 2006. Fluvial fluxes into the Caribbean Sea and their impact on coastal ecosystems: The Magdalena River, Colombia. Global Planet. Change 50: 33-49.

Riegl, B. 2001. Degradation of reef structure, coral and fish communities in the Red Sea by ship groundings and dynamite fisheries. Bull. Mar. Sci. 69: 595-611.
Riegl B. \& W.E. Piller. 2003. Possible refugia for reefs in times of environmental stress. Int. J. Earth Sci. 92: 520-531.

Roberts, J.M., C.J. Brown, D. Long \& C.R. Bates. 2005. Acoustic mapping using a multibeam echosounder reveals cold-water coral reefs and surrounding habitats. Coral Reefs 24: 654-669.

Rogers, C.S. 1990. Reponses of coral reefs and reef organisms to sedimentation. Mar. Ecol. Prog. Ser. 62: 185-202.

Rogers, C.S. \& J. Beets. 2001. Degradation of marine ecosystems and decline of fishery resources in marine protected areas in the US Virgin Islands. Environ. Conserv. 28: 312-322.

Rogers, C.S. \& J. Miller. 2006. Permanent 'phase shifts’ or reversible declines in coral cover? Lack of recovery of two coral reefs in St. John, US Virgin Islands. Mar. Ecol. Prog. Ser. 306: 103-114.

Smith, N.P. 2001. Weather and hydrographic conditions associated with coral bleaching: Lee Stocking Island, Bahamas. Coral Reefs 20: 415-422.

Wilkinson, C. 2004. Status of Coral Reefs of the World. Australia Institute of Marine Science, Townsville, Australia. 301 p.

Wilkinson C. 2004. Status of coral reefs of the world. Vol. 1. Townsville, Australia, Australia Institute of Marine Science. 301 p. 


\section{APPENDIX A}

Sample of scientific articles acquired from the Science Citation Index Expanded (ISI Web of Science, Thomson Scientific). Articles 1-50 represent sample from keyword search "coral OR corals” and articles 51-101 represent sample from keyword search "coral OR corals AND health OR mortal”. Article order reflects article identification number in Figure 2.

1. $\quad$ Pari N., M. Peyrot-Clausade \& P.A. Hutchings. 2002. Bioerosion of experimental substrates on high islands and atoll lagoons (French Polynesia) during 5 years of exposure. J. Exp. Mar. Biol. Ecol. 276: 109-127.

2. Hoogenboom M.O., K. R.N. Anthony \& S.R. Connolly. 2006. Energetic cost of photoinhibition in corals. Mar. Ecol. Prog. Ser. 313: 1-12.

3. West J.M. 1997. Plasticity in the sclerites of a gorgonian coral: tests of water motion, light level, and damage cues. Biol. Bull. 192: 279-289.

4. Kramarsky-Winter E., M. Harel, N. Siboni, E. Ben Dov, I. Brickner, Y. Loya \& A. Kushmaro. 2006. Identification of a protist-coral association and its possible ecological role. Mar. Ecol. Prog. Ser. 317: 67-73.

5. Takabayashi M. \& O. Hoegh-Guldberg. 1995. Ecological and physiological differences between two colour morphs of the coral Pocillopora damicornis. Mar. Biol. 123(4): 705-714.

6. Nakamura T., R. van Woesik \& H. Yamasaki. 2005. Photoinhibition of photosynthesis is reduced by water flow in the reef-building coral Acropora digitifera. Mar. Ecol. Prog. Ser. 301: 109-118.

7. Walmsley S.F. \& A. T. White. 2003. Influence of social, management and enforcement factors on the long-term ecological effects of marine sanctuaries. Environ. Conserv. 30: 388-407.

8. Ralph P.J., A. W.D. Larkum \& M. Kühl. 2005. Temporal patterns in effective quantum yield of individual zooxanthellae expelled during bleaching. J. Exp. Mar. Biol. Ecol. 316: 17-28.

9. Potts D.C. 1984. Natural selection in experimental populations of reef-building corals. Evolution. 38: 1059-1078.

10. Vroom P.S., K.N. Page, K.A. Peyton \& J.K. KukeaShultz. 2005. Spatial heterogeneity of benthic community assemblages with an emphasis on reef algae at French Frigate Shoals, Northwestern Hawai'ian Islands. Coral Reefs 24: 574-581.

11. Neves E.G. \& F.L. de Silveira. 2003. Release of planula larvae, settlement and development of Siderastrea stellata Verrill, 1868 (Anthozoa, Scleractinia). Hydrobiologia. 501: 139-147.

12. Levy O., Z. Dubinsky, K. Schneider, Y. Achituv, D. Zakai \& M.Y. Gorunov. 2004. Diurnal hysteresis in coral photosynthesis. Mar. Ecol. Prog. Ser. 268: 105-117.

13. Rogers C.S., H.C. Fitz III, M. Gilnack, J. Beets \& J. Hardin. 1984. Scleractinian coral recruitment patterns at Salt River Submarine Canyon, St. Croix, US Virgin Islands. Coral Reefs 3: 69-76.

14. Riegl B. \& A. Riegl. 1996. Studies on coral community structure and damage as a basis for zoning marine reserves. Biol. Conserv. 77: 269-277.

15. Gleason D.F. 1998. Sedimentation and distributions of green and brown morphs of the Caribbean coral Porites astreoides Lamark. J. Exp. Mar. Biol. Ecol. 230: 73-89.

16. Bush S.L., W.F. Precht, J.D. Woodley \& J.F. Bruno. 2002. Indo-Pacific mushroom corals found on Jamaican reefs. Coral Reefs 23: 234.

17. Drollet J.H., M. Faucon, S. Maritorena \& P.M.V. Martin. 1994. A survey of environmental physicochemical parameters during a minor coral mass bleaching event in Tahiti in 1993. Aust. J. Mar. Freshw. Res. 45: 1149-1156.

18. Leuzinger S., K.R.N. Anthony \& B.L. Willis. 2003. Reproductive energy investment in corals: scaling with module size. Oecologia 136: 524-531.

19. Crabbe M.J.C. \& D.J. Smith. 2002. Comparison of two reef sites in the Wakatobi Marine National Park (SE Sulawesi, Indonesia) using digital image analysis. Coral Reefs 21: 242-244.

20. Levy O., Y. Achituv, Y.Z. Yacobi, N. Stambler \& Z. Dubinsky. 2006. The impact of spectral composition and light periodicy on the activity of two antioxidant enzymes (SOD and CAT) in the coral Favia favus. J. Exp. Mar. Biol. Ecol. 328: 35-46.

21. Meroz E. \& M. Ilan. 1995. Cohabitation of a coral reef sponge and colonial scyphozoan. Mar. Biol. 124: 453-459. 
22. Chiappone M., K. Sullivan-Sealy, G. Bustamante \& J. Tschirky. 2001. A rapid assessment of coral reef community structure and diversity patterns a naval station Guantánamo Bay, Cuba. Bull. Mar. Sci. 69: 373-394.

23. Williams,D.E. \& M.W. Miller. 2005. Coral disease outbreak: pattern, prevalence and transmission in Acropora cervicornis. Mar. Ecol. Prog. Ser. 301: 119-128.

24. Sherwood O.A., J.M. Heikoop, D.B. Scott, M.J. Risk, T.P. Guilderson \& R.A. McKinney. 2005. Stable isotopic composition of deep-sea gorgonian corals Primnoa spp.: a new archive of surface processes. Mar. Ecol. Prog. Ser. 301: 135-148.

25. Lewis J.B. 2002. Evidence from aerial photography of structural loss of coral reefs at Barbados, West Indies. Coral Reefs 21: 49-56.

26. Marshall P.A. 2000. Skeletal damage in reef corals: relating resistance to colony morphology. Mar. Ecol. Prog. Ser. 200: 177-189.

27. Mitchell N.D., M.R. Dardeau, W.W. Schroeder \& A.C. Benke. 1992. Secondary production of gorgonian corals in the northern Gulf of Mexico. Mar. Ecol. Prog. Ser. 87: 275-281.

28. Nemeth R.S. \& J. Sladek Nowlis. 2001. Monitoring the effects of land development on the near-shore reef environment of St. Thomas, USVI. Bull. Mar. Sci. 69: 759-775.

29. Littler M.M., D.S. Littler, B.L. Brooks \& B.E. Lapointe. 2006. Nutrient manipulation methods for coral reef studies: a critical review and experimental field data. J. Exp. Mar. Biol. Ecol. 336: 242-253.

30. Lam K., P.K.S. Shin, R. Bradbeer, D. Randall, K.K.K. Ku, P. Hodgson \& S.G. Cheung. 2006. A comparison of video and point intercept transect methods for monitoring subtropical coral communities. J. Exp. Mar. Biol. Ecol. 333: 115-128.

31. Risk M.J., J.M. Heikoop, M.G. Snow \& R. Beukens. 2002. Lifespans and growth patterns of two deep-sea corals: Primnoa resedaeformis and Desmophyllum cristagalli. Hydrobiologia. 471: 125-131.

32. Goffredo S., S. Arnone \& F. Zaccanti. 2002. Sexual reproduction in the Mediterranean solitary coral, Balanophyllia europaea (Scleractinia, Dendrophylliidae). Mar. Ecol. Prog. Ser. 229: 83-94.

33. Baird A.H. \& P.A. Marshall. 2002. Mortality, growth and reproduction in the scleractinian corals following bleaching on the Great Barrier Reef. Mar. Ecol. Prog. Ser. 237: 133-141.
34. Vize P.D. 2006. Deepwater broadcast spawning by Montastraea cavernosa, Montastraea franksi, and Diploria strigosa at the Flower Garden Banks, Gulf of Mexico. Coral Reefs 25: 169-171.

35. Hoeksema B.W. 1991. Control of bleaching in mushroom coral populations (Scleractinia: Fungiidae) in the Java Sea: stress tolerance and interference by life history strategy. Mar. Ecol. Prog. Ser. 74: 225-237.

36. Lesser M.P. \& M.Y. Gorbunov. 2001. Diurnal and bathymetric changes in chlorophyll fluorenscence yields of reef corals measured in situ with a fast repetition rate fluorometer. Mar. Ecol. Prog. Ser. 212: 69-77.

37. Guzmán H.M. \& I. Holst. 1993. Effects of chronic oil-sediment pollution on the reproduction of the Caribbean reef coral Siderastrea siderea. Mar. Pollut. Bull. 26: 276-282.

38. Gast G.J., S. Wiegman, E. Wieringa, F.C. van Duyl \& R.P. M. Bak. 1998. Bacteria in coral reef water types: removal of cells, stimulation of growth and mineralization. Mar. Ecol. Prog. Ser. 167: 37-45.

39. Grottoli A. G. 1999. Variability of stable isotopes and maximum linear extension in reef-coral skeletons at Kaneohe Bay, Hawaii. Mar. Biol. 135: 437-449.

40. Kingston P. 2003. News: Scotland's deep-water corals to be protected. Mar. Pollut. Bull. 46: 1215-1218.

41. Mumby P.J., J.D. Hedley, J.R.M. Crisholm, C.D. Clark, H. Ripley \& J. Jaubert. 2004. The cover of living and dead corals from airborne remote sensing. Coral Reefs 23: 171-183.

42. Hunter C.L. \& C.W. Evans. 1995. Coral reefs in Kaneohe Bay, Hawaii: two centuries of western influence and two decades of data. Bull. Mar. Sci. 57: 501-515.

43. Pires D.O., C.B. Castro \& C.C. Ratto. 1999. Reef coral reproduction in the Abrolhos Reef Complex, Brazil: the endemic genus Mussismilia. Mar. Biol. 135: 463-471.

44. Torrents O., J. Garrabou, C. Marschal \& J.G. Harmelin. 2005. Age and size a first reproduction in the commercially exploited red coral Corallium rubrum (L.) in the Marseilles area (France, NW Mediterranean). Biol. Conserv. 121: 391-397.

45. Dizon R.T. \& H.T. Yap. 2006. Effects of coral transplantation in sites of varying distances and environmental conditions. Mar. Biol. 148: 933-943.

46. Kumarsingh K., R. Laydoo, J.K. Chen \& A.M. Siung-Chang. 1998. Historic records of phosphorous 
levels in the reef-building coral Montastrea annularis from Tobago, West Indies. Mar. Pollut. Bull. 36: 1012-1018.

47. Nozawa Y., M. Tokeshi \& S. Nojima. 2006. Reproduction and recruitment of scleractinian corals in a high-latitude coral community, Amakusa, southwestern Japan. Mar. Biol. 149: 1047-1058.

48. Diekmann O.E., R.P.M. Bak, L. Tonk, W.T. Stam \& J.L. Olsen. 2002. No habitat correlation of zooxanthellae in the coral genus Madracis on a Curacao reef. Mar. Ecol. Prog. Ser. 227: 221-232.

49. Kemp J.M. \& F. Benzoni. 1999. Monospecific coral areas on the northern shore of the Gulf of Aden, Yemen. Coral Reefs 18: 280.

50. Schleyer M.H. \& L. Celliers. 2003. Coral dominance at the reef-sediment interface in marginal coral communities at Sodwana Bay, South Africa. Mar. Freshw. Res. 54: 967-972.

51. Sample of scientific articles acquired from the Science Citation Index Expanded (ISI Web of Science, Thomson Scientific) using keyword search "coral OR corals AND health OR mortal*”

52. Glassom D. \& N. E. Chadwick. 2006. Recruitment, growth and mortality of juvenile corals as Eilat, northern Red Sea. Mar. Ecol. Prog. Ser. 318: 111-122.

53. Wolanski E., K. Fabricius, S. Spagnol \& R. Brinkman. 2005. Fine sediment budget on an inner-shelf coralfringed island, Great Barrier Reef of Australia. Estuar. Coast. Shelf Sci. 65: 153-158.

54. Larkum A.W.D. \& A.D.L. Steven. 1994. The effect of nutrient enrichment on coral reefs. 1. Experimental design and research programme. Mar. Pollut. Bull. 29: $112-120$.

55. Holmes K.E., E.N. Edinger, Hariyadi, G.V. Limmon \& M.J. Risk. 2000. Bioerosion of live massive corals and branching coral rubble on Indonesian coral reefs. Mar. Pollut. Bull. 40(7): 606-617.

56. Feingold J.S. 2001. Responses of three coral communities to the 1997-98 El Niño-Southern Oscillation: Galapagos Islands, Ecuador. Bull. Mar. Sci. 69: 61-77.

57. McClanahan T.R., A.H. Baird, P.A. Marshall \& M.A. Toscano. 2004. Comparing bleaching and mortality responses of hard corals between southern Kenya and the Great Barrier Reef, Australia. Mar. Pollut. Bull. 48: 327-335.
58. Nugues M.M. \& R.P.M. Bak. 2006. Differential competitive abilities between Caribbean coral species and a brown alga: a year of experiments and a long-term perspective. Mar. Ecol. Prog. Ser. 315: 75-86.

59. Geffen Y. \& E. Rosenberg. 2005. Stress-induced rapid release of antibacterials by scleractinian corals. Mar. Biol. 146: 931-935.

60. Dalton S.J. \& S. D.A. Smith. 2006. Coral disease dynamics at a subtropical location, Solitary Islands Marine Park, eastern Australia. Coral Reefs 25: 37-45.

61. Edmunds P.J., R.D. Gates \& D.F. Gleason. 2003. The tissue composition of Montastraea franksi during a natural bleaching event in the Florida Keys. Coral Reefs 22: 54-62.

62. Coma R., E. Pola, M. Ribes \& M. Zabala. 2004. Long-term assessment of temperate octocoral mortality patterns, protected vs. unprotected areas. Ecol. Appl. 14: 1466-1478.

63. Kim K., A.P. Alker, K. Shuster, C. Quirolo \& C.D. Harvell. 2006. Longitudinal study of aspergillosis in sea fan corals. Dis. Aquat. Org. 69: 95-99.

64. Yoshioka P.M. 1996. Variable recruitment and its effects on the population and community structure of shallow-water gorgonians. Bull. Mar. Sci. 59: 433-443.

65. Bastidas C., K.E. Fabricius \& B.L. Willis. 2004. Demographic aspects of the soft coral Sinularia flexibilis leading to local dominance on coral reefs. Hydrobiologia. 530-531: 433-441.

66. Linares C., R. Coma, D. Diaz, M. Zabala, B. Hereu \& L. Dantart. 2005. Immediate and delayed effects of a mass mortality event on gorgonian population dynamics and benthic community structure in the NW Mediterranean Sea. Mar. Ecol. Prog. Ser. 305: 127-137.

67. McClanahan T.R., J. Maina, R. Moothien-Pillay \& A.C. Baker. 2005. Effects of geography, taxa, water flow, and temperature variation on coral bleaching intensity in Mauritius. Mar. Ecol. Prog. Ser. 298: 131-142.

68. Chadwick N.E. 1991. Spatial distribution and the effects of competition on some temperate Scleractinia and Corallimorpharia. Mar. Ecol. Prog. Ser. 70: 39-48. 
69. Glynn P. W., J.E.N. Veron \& G.M. Wellington. 1996. Clipperton Atoll (eastern Pacific): oceanography, geomorphology, reef-building coral ecology and biogeography. Coral Reefs 15: 71-99.

70. Jordán-Dahlgren E. 1992. Recolonization patterns of Acropora palmata in a marginal environment. Bull. Mar. Sci. 51: 104-117.

71. Goffredo S. \& N.E. Chadwick-Furman. 2003. Comparative demography of mushroom corals (Scleractinia: Fungiidae) at Eilat, northern Red Sea. Mar. Biol. 142: 411-418.

72. Meesters E.H., I. Wesseling \& R.P.M. Bak. 1997. Coral colony tissue damage in six species of reefbuilding corals: partial mortality in relation with depth and surface area. J. Sea. Res. 37: 131-144.

73. Oigman-Pszczol S.S. \& J.C. Creed. 2004. Size structure and spatial distribution of the corals Mussimilia hispida and Siderastrea stellata (Scleractinia) at Armaçáo dos Búzios, Brazil. Bull. Mar. Sci. 74: 433-448.

74. Ruesink J.L. 1997. Coral injury and recovery: matrix models link process to pattern. J. Exp. Mar. Biol. Ecol. 210: 187-208.

75. Nugues M.M. \& C.M. Roberts. 2003. Partial mortality in massive reef corals as an indicator of sediment stress on coral reefs. Mar. Pollut. Bull. 46: 314-323.

76. Buckley B.A. \& A.M. Szmant. 2004. RNA/DNA ratios as indicators of metabolic activity in four species of Caribbean reef-building corals. Mar. Ecol. Prog. Ser. 282: 143-149.

77. Clark S. \& A.J. Edwards. 1995. Coral transplantation as an aid to reef rehabilitation: evaluation of a case study in the Maldive Islands. Coral Reefs 14: 201-213.

78. Shenkar N., M. Fine \& Y. Loya. 2005. Size matters: bleaching dynamics of the coral Oculina patagonica. Mar. Ecol. Prog. Ser. 294: 181-188.

79. Aronson R.B., I.G. Macintyre, W.F. Precht, T.J.T. Murdoch \& C.M. Wapnick. 2002. The expanding scale of species turnover events on coral reefs in Belize. Ecol. Monogr. 72: 233-249.

80. Kobluk D.R. \& M.A. Lysenko. 1994. "Ring” bleaching in southern Caribbean Agaricia agaricites during rapid water cooling. Bull. Mar. Sci. 54: 142-150.

81. Turner S.J. 1994. Spatial variability in the abundance of the corallivorous gastropod Drupella cornus. Coral Reefs 13: 41-48.
82. Finelli C.M., B.S.T. Helmuth, N.D. Pentcheff \& D.S. Wethey. 2006. Water flow influences oxygen transport and photosynthetic efficiency in corals. Coral Reefs 25: 47-57.

83. Meesters E.H., M. Hilterman, E. Hardinaal, M. Keetman, M. de Vries \& R.P.M. Bak. 2001. Colony size-frequency distributions of scleractinian coral populations: spatial and interspecific variation. Mar. Ecol. Prog. Ser. 209: 43-54.

84. Black N.A., R. Voellmy \& A.M. Szmant. 1995. Heat shock protein induction in Montastraea faveolata and Aiptasia pallida exposed to elevated temperatures. Biol. Bull. 188: 234-240.

85. Chen C.A., J.T. Wang, L.S. Fang \& Y.W. Yang. 2005. Fluctuating algal symbiont communities in Acropora palifera (Scleractinia: Acroporidae) from Taiwan. Mar. Ecol. Prog. Ser. 295: 113-121.

86. Witman J.D. 1992. Physical disturbance and community structure of exposed and protected reefs: a case study from St. John, US Virgin Islands. Amer. Zool. 32: 641-654.

87. Fabricius K.E. 1995. Slow population turnover in the soft coral genera Sinularia and Sarcophyton on midand outer-shelf reefs of the Great Barrier Reef. Mar. Ecol. Prog. Ser. 126: 145-152.

88. Bruckner A.W. \& R.J. Bruckner. 2001. Condition of restored Acropora palmata fragments off Mona Island, Puerto Rico, 2 years after the Fortuna Reefer ship grounding. Coral Reefs 20: 235-243.

89. Ninio R. \& M.G. Meekan. 2002. Spatial patterns in benthic communities and dynamics of mosaic ecosystems on the Great Barrier Reef, Australia. Coral Reefs 21: 95-103.

90. McClanahan T.R. 2004. The relationship between bleaching and mortality of common corals. Mar. Biol. 144: 1239-1245.

91. Sitger V. \& C.E. Payri. 2005. Natural settlement dynamics of a young population of Turbinaria ornata and phenological comparisons with older populations. Aquat. Bot. 81: 225-243.

92. Acosta A. 2001. Disease in Zoanthids: dynamics in space and time. Hydrobiologia. 460: 113-130.

93. Yap H.T., R.M. Alvarez, H.M. Custodio III \& R.M. Dizon. 1998. Physiological and ecological aspects of coral transplantation. J. Exp. Mar. Biol. Ecol. 229: 69-84. 
94. Goffredo S., G. Mattioli \& F. Zaccanti. 2004. Growth and population dynamics model of the Mediterranean solitary coral Balanophyllia europaea (Scleractinia, Dendrophylliidae). Coral Reefs 23: 433-443.

95. Franklin D.J., O. Hoegh-Guldberg, R.J. Jones \& J.A. Berges. 2004. Cell death and degeneration in the symbiotic dinoflagellates of the coral Stylophora pistillata during bleaching. Mar. Ecol. Prog. Ser. 272: $117-130$.

96. Aerts L.A.M. \& R.W.M. van Soest. 1997. Quantification of sponge/coral interactions in a physically stressed reef community, NE Colombia. Mar. Ecol. Prog. Ser. 148: 125-134.

97. Morgan M.B., S.E. Edge \& T.W. Snell. 2005. Profiling differential gene expression of corals along a transect of waters adjacent to the Bermuda municipal dump. Mar. Pollut. Bull. 51: 524-533.
98. Richardson L.L. \& J.D. Voss. 2005. Changes in a coral population on reefs of the northern Florida Keys following a coral disease epizootic. Mar. Ecol. Prog. Ser. 297: 147-156.

99. Andréfouët S. \& H.M. Guzman. 2005. Coral reef distribution, status and geomorphology-biodiversity relationship in Kuna Yala (San Blas) archipelago, Caribbean Panama. Coral Reefs 24: 31-42.

100. Thornhill D.J., T.C. LaJeunesse, D.W. Kemp, W.K. Fitt \& G.W. Schmidt. 2006. Multi-year, seasonal genotypic surveys of coral-algal symbioses reveal prevalent stability or post-bleaching reversion. Mar. Biol. 148: 711-722.

101. Rotjan R.D., J.L. Dimond, D.J. Thornhill, J.J. Leichter, B. Helmuth, D.W. Kemp \& S.M. Lewis. 2006. Chronic parrotfish grazing impedes coral recovery after bleaching. Coral Reefs 25: 361-368. 